\title{
Chemical Processes Affecting the Mobility of Heavy Metals and Metalloids in Soil Environments
}

\author{
Antonio G. Caporale ${ }^{1}$ - Antonio Violante ${ }^{1}$
}

Published online: 23 December 2015

(C) Springer International Publishing AG 2015

\begin{abstract}
The mobility, bioavailability, and toxicity of metal(loid)s are influenced by their interactions with phyllosilicates, organic matter, variable charge minerals, and microorganisms. Physicochemical processes influencing the chemistry of metal(loid)s in soil environments include sorption/desorption, solution complexation, oxidation-reduction, and precipitationdissolution reactions. In particular, the sorption/desorption reactions of metal(loid)s on/from soil sorbents are influenced by $\mathrm{pH}$, nature of soil components, and presence and concentrations of cations and inorganic anions. In recent years, many extraction tests have been used for assessing trace elements mobility and phytoavailability. Chemical speciation of toxic elements may be achieved by spectroscopic analyses (XAS), which provide information about oxidation state, symmetry, and identity of the coordinating ligand environment, and possible solid phases.
\end{abstract}

Keywords Chemical processes $\cdot$ Heavy metals $\cdot$ Metalloids . Mobility $\cdot$ Bioavailability $\cdot$ Soil environments

\section{Introduction}

Sorption-desorption reactions are the predominant processes that control the bioavailability of metals and metalloids in soils. The soil components responsible for the sorption of cations and anions include phyllosilicates, soil organic matter, variable charge minerals (crystalline and short-range ordered

This article is part of the Topical Collection on Land Pollution

Antonio G. Caporale

ag.caporale@unina.it

1 Dipartimento di Agraria, Università degli Studi di Napoli Federico II, 80055 Portici, Napoli, Italy
Fe-, Al-, Mn-oxides, phyllosilicates coated by $\mathrm{OH}-\mathrm{Al}$ and $\mathrm{OH}-\mathrm{Fe}$ species), carbonates, microorganisms, and organomineral complexes. Soil components differ greatly in their sorption capacities, their cation and anion exchange capacities, and the binding energies of their sorption sites $[1,2]$.

Two surface complexes exist and are described by the configuration geometry of the sorbate at the sorbent surface. These include inner- and outer-sphere surface complexes [1, 3]. Outer-sphere complexes involve electrostatic coulombic interactions and are thus weak compared with inner-sphere and are reversible. An outer-sphere surface complex has at least one interposed water molecule between the surface functional group of a soil component and the ion or molecule it binds, whereas an inner-sphere surface complex has no water molecules interposed, the ion being held through bonds with a covalent character (Fig. 1). Recently, Lee et al. [4], by using in situ resonant anomalous X-ray reflectivity, found three forms of sorbed cations: the classical outer-sphere and inner-sphere complexes and an "extended" outer-sphere complex located above the surface hydration layer or maintaining intact higherorder hydration shell (Fig. 1). Inner- and outer-sphere complexations can occur simultaneously. Specific sorption is characterized by higher selectivity and stronger binding (weaker reversibility), while nonspecific sorption is known for lower selectivity and greater reversibility. The strength of the sorption of cations and anions is an important factor governing their mobility in soils. Sorption of elements onto soil components is influenced by many factors as $\mathrm{pH}$, nature of the sorbents, redox reactions, and the presence of foreign ions [1, 2, $5,6]$. Briefly, cations show typical ion exchange behavior on clay minerals because surface bonding is prevalently electrostatic. Studies using in situ molecular scale technique such as X-ray absorption spectroscopy (XAS), X-ray absorption near edge structure (XANES), extended X-ray absorption fine structure (EXAFS), or Fourier transform infrared (FTIR) 


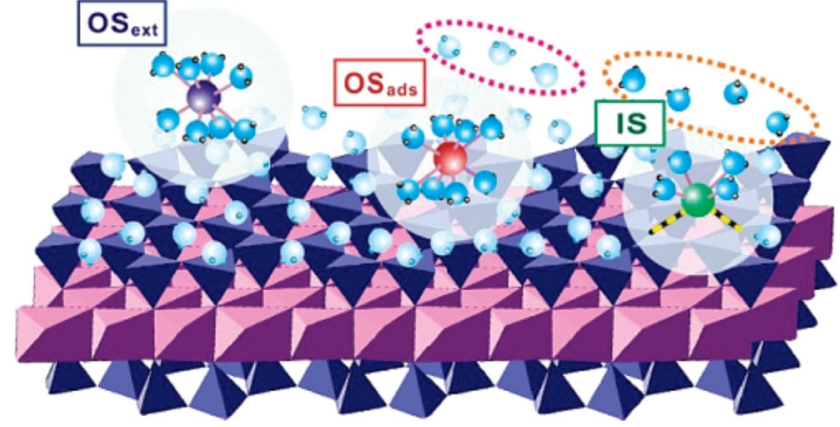

Fig. 1 Schematic of interfacial cation speciation near the muscovite (001)-solution interface. A hydrated cation adsorbs at the interface as an extended outer-sphere $\left(O S_{\text {ext }}\right)$ complex (dark blue, on the left) when it is located above the surface hydration layer (light-blue water molecules) or maintains intact higher-order hydration shells. A cation, which retains its primary hydration shell, adsorbs on the surface as an adsorbed outersphere $\left(O S_{a d s}\right)$ complex (red, middle) after displacing the hydration layer of the muscovite surface (light-blue water molecules in a magenta region). Inner-sphere (IS) complexation (green, on the right) requires additional dehydration from the ion's first hydration shell (cyan water molecules in an orange region) to form direct bonds (yellow dashed lines) with the surface oxygen atoms (from Lee et al. [4], permission by ACS Publications)

spectroscopy suggest that alkaline earth cations form mainly outer-sphere complexes, but polyvalent cations (e.g., $\mathrm{Zn}, \mathrm{Cu}$, $\mathrm{Ni}, \mathrm{Pb}, \mathrm{Hg}, \mathrm{Cd}, \mathrm{Co}, \mathrm{Ca}$ ) may be strongly adsorbed on the edge sites of phyllosilicates due to the presence of $-\mathrm{SiOH}$ or $\mathrm{AlOH}$ groups capable of chemisorbing these ions [7, 8]. Organic matter and variable charge minerals (metal oxides, allophanes, imogolite) are much more effective scavengers of polyvalent cations because complexation processes are the dominant binding mechanisms $[5,6,9,10]$. Usually, specifically sorbed cations raise the value of the point of zero charge (PZC, i.e., the $\mathrm{pH}$ value at which the electrical charge density on a mineral surface is equal to zero) of variable charge minerals. The $\mathrm{pH}$ affects the sorption of metal cations on variable charge minerals either by changing the number of sites available for sorption (sorption increases by increasing $\mathrm{pH}$ ) or by changing the concentration of cation species $\left[\mathrm{Me}^{2+}, \mathrm{MeOH}^{+}\right.$, $\left.\mathrm{Me}(\mathrm{OH})_{2}\right]$. Evidence on the sorption of heavy metals on microorganisms has been reported. The cell surfaces of all bacteria are largely negatively charged, containing different types of negatively charged functional groups, such as carboxyl, hydroxyl, and phosphoryl that can sorb metal cations. Biosorption comprises a variety of processes including ion exchange, chelation, sorption, and diffusion through cell walls and membranes, all of which are dependent on the species used, the biomass origin, and solution chemistry [11].

Many factors, such as $\mathrm{pH}$, surface coverage, ionic strength (I), nature of the sorbent, and residence time, affect the type of sorption complex. Strawn and Sparks [12] demonstrated that at $\mathrm{pH} 4.48$ and $\mathrm{I}$ of $0.06 \mathrm{~Pb}$ was sorbed in the interlayers of montmorillonite forming outer-sphere complexes, whereas at $\mathrm{pH} 6.77$ and I of 0.1 the heavy metal was fixed forming mainly inner-sphere complexes on the edge sites of the phyllosilicate.

Toxic elements in anionic form sorb primarily to variable charge minerals (metal oxides and noncrystalline aluminum silicates, allophanes), carbonate, and at the edges of phyllosilicates. Usually, they are not sorbed on soil organic matter, but certain elements (e.g., borate, arsenate, arsenite, selenite) are found to be bound to humic substances $[1,2$, 10, 13, 14]. The sorption of As onto organic matter may be facilitated by the presence of amino groups, due to their positive charge, and thiol groups ( $\mathrm{SH}$ ) which have a high affinity for As. Indeed, some anions may bond indirectly to organic groups through a bridging with hydrolytic species of $\mathrm{Al}$ and Fe held on humic substances forming ternary As complexes [15]. According to Sharma et al. [16, 17] and Mitsunobu et al. [18], a similar mechanism with much greater affinity to organic matter could be expected with $\mathrm{Sb}$ [19].

Sorption of anions onto variable charge minerals and soils varies with $\mathrm{pH}$. With increasing $\mathrm{pH}$ values, sorption usually decreases due to a decrease in the positive charge of minerals. Ligands that are specifically sorbed, forming inner-sphere complexes, e.g., arsenate, arsenite (on Fe-oxides), molybdate, and selenite, replace $-\mathrm{OH}^{-}$or $-\mathrm{OH}_{2}$ groups from the surfaces of variable charge minerals. They may form different surface complexes: monodentate, bidentate-binuclear, and bidentatemononuclear complexes in different proportions depending on the $\mathrm{pH}$ and surface coverage $[1,3,6]$. Selenate seems to form mainly outer-sphere complexes [1]. However, there is some spectroscopic evidence that it can be also sorbed as both an outer-sphere and an inner-sphere complex, depending on environmental factors [20]. Inner-sphere complexation of selenate onto the surfaces of variable charge minerals seems to be facilitated at low $\mathrm{pH}$ values. Lafferty et al. [21] demonstrated that arsenate sorbed onto a manganese oxide formed bidentate binuclear and monodentate mononuclear complexes after a few hours, but at longer time a bidentate-mononuclear complex also formed.

It is important to consider that if more surface species are formed on a sorbent, spectroscopic techniques usually detect the primary type of surface complex. However, if the identified primary surface complex is inner-sphere, this does not mean that outer-sphere complexation is not occurring. Through the use of X-ray scattering measurements to study metal(loid) binding on single crystal surfaces, indeed, Catalano et al. [22] showed that arsenate surface complexation was bimodal, with sorption occurring simultaneously as innerand outer-sphere species.

Recently, Ha et al. [23, 24] found that even variations in hematite particle sizes (nanoparticles with average diameter of $10.5 \mathrm{~nm}$ and microparticles with average diameter of $550 \mathrm{~nm}$ ) affect the modes of $\mathrm{Zn}$ sorption, leading to the formation of different types of surface complexes and/or precipitates. 


\section{Metal(Loid) Surface Precipitation}

As the amount of cations or anions sorbed onto the surfaces of a mineral increases (surface coverage), the sorption changes from mononuclear adsorption to surface precipitation (a threedimensional phase) $[3,8,25]$. In the last decade, many studies have shown that at high metal loadings (also below the theoretical metal-monolayer coverage of sorbent surfaces) sorption of some cations, such as $\mathrm{Ni}, \mathrm{Co}, \mathrm{Cr}$, and $\mathrm{Zn}$, on the surfaces of Al-oxides and Al-bearing phyllosilicates may promote the formation of precipitates such as double layered hydroxides (LDHs) at $\mathrm{pH}$ values below the $\mathrm{pH}$ where the formation of metal hydroxide precipitate is expected according to the solubility product $[3,7,8]$. LDHs are a group of minerals whose structural formula is $\left[\mathrm{M}^{2+}{ }_{1-\mathrm{x}} \mathrm{M}^{3+}{ }_{\mathrm{x}}(\mathrm{OH})_{6}\right]^{\mathrm{x}+}\left[\left(\mathrm{A}^{\mathrm{n}-}\right)_{\mathrm{x} / \mathrm{n}}\right.$ $\left.\mathrm{m} \mathrm{H}_{2} \mathrm{O}\right]^{\mathrm{x}-}$, where $\mathrm{M}^{2+}$ could be $\mathrm{Mg}, \mathrm{Ni}, \mathrm{Co}, \mathrm{Zn}$ and $\mathrm{M}^{3+}$ could be $\mathrm{Al}, \mathrm{Fe}, \mathrm{Cr}$. The structure of LDHs can be described as a positively charged brucite-like sheet, where a fraction of the divalent cations coordinated octahedrally by hydroxyl groups have been isomorphously replaced by trivalent cations, giving positively charged sheets. The net positive charge is balanced by anions such as $\mathrm{CO}_{3}, \mathrm{Cl}, \mathrm{NO}_{3}, \mathrm{SO}_{4}$, and $\mathrm{ClO}_{4}$ which are present in the interlayers of the mineral [26, 27]. The formation of metal surface precipitates can sequester heavy metals with a consequent reduction of metal release and bioavailability for plants and microorganisms [8]. As reported by Sparks and coworkers [1, 3, 7, 8, 25], sorption of select heavy metals $(\mathrm{Co}, \mathrm{Ni}, \mathrm{Zn})$ on soil minerals involves a continuum of processes from adsorption to precipitation to solid phase transformation.

\section{Abiotic Redox Processes}

Metal(loid)s may exist in more than one oxidation state. Redox reactions play an important role in controlling their transformation, mobility, and toxicity. Abiotic redox processes occur on the surfaces of humic substances, Fe(III)- and Mnoxides, sulfides, and ferrous species. Redox reactions also control the transformation and $\mathrm{Fe}$ - and Mn-oxides reactivity, which are the major sinks of metal(loid)s in soils. The efficiency of Mn oxides as an "electron pump" for a wide range of redox reactions is unique among common soil minerals [28]. Manganese oxides are able to oxidize some metal cations such as $\mathrm{Pb}, \mathrm{Co}, \mathrm{Cu}$, and $\mathrm{Ni}$ on $\mathrm{Mn}$ mineral surface.

Metal(loid)s often have different degrees of toxicity depending on the specific metal oxidation state. For example, arsenic is intimately related to the presence of iron and manganese (hydr)oxides, since both arsenite and arsenate show high affinity for the surfaces of these oxides. Arsenite is more toxic and bioavailable than $\mathrm{As}(\mathrm{V})$. Manganese oxides are capable of oxidizing $\mathrm{As}(\mathrm{III})$ to $\mathrm{As}(\mathrm{V})$ so this oxidation process has important implications for the mobility and toxicity of arsenic. Manganese oxides catalyze the oxidation of other heavy metals such as $\mathrm{Co}, \mathrm{Pb}, \mathrm{Ni}$, and $\mathrm{Cu}$. Sun and Doner [29] demonstrated that oxidation of sorbed $\mathrm{As}(\mathrm{III})$ to $\mathrm{As}(\mathrm{V})$ on Fe-oxides may occur to a limited (about $20 \%$ ) extent. In contrast, reducing conditions may release As into solution through reduction of $\mathrm{Fe}$ and $\mathrm{Mn}$ oxides and reduction of As(V) to As(III).

Chromate is toxic to plants, animals, and humans and is a suspected carcinogen whereas $\mathrm{Cr}(\mathrm{III})$ is not toxic to plants and is necessary in animal nutrition, so reactions that reduce $\mathrm{Cr}(\mathrm{VI})$ to $\mathrm{Cr}(\mathrm{III})$ are of great importance. Furthermore, $\mathrm{Cr}(\mathrm{VI})$ is mobile in soils and readily available. Organic material, sulfides, and ferrous species appear to be the dominant reductants. Very stable $\mathrm{Cr}(\mathrm{III})$-organic complexes form when $\mathrm{Cr}(\mathrm{VI})$ is reduced by soil organic matter $[28,30]$. Effective sorption and reduction of $\mathrm{Cr}(\mathrm{VI})$ by humic acid coated on magnetite has been recently demonstrated by XANES [31]. This work demonstrated that humic acid (HA) was responsible of $\mathrm{Cr}(\mathrm{VI})$ reduction while the valence state of the iron in magnetite remained unchanged.

Selenium can exist in a wide range of oxidation states. It is an essential element in a wide range of organisms from bacteria to humans at low concentration, but it is extremely toxic at high concentrations. Selenite [Se(IV)] is more toxic than selenate [Se(VI)]. Birnessite is able to oxidize $\mathrm{Se}(\mathrm{IV})$ to $\mathrm{Se}(\mathrm{VI})$, while the oxidation of $\mathrm{Fe}(\mathrm{II})$-bearing minerals may lead to the reductive immobilization of aqueous Se(IV) to $\mathrm{Se}(0)$ [32]. The geochemical cycling of Se parallels that of sulfur so Se is predominantly cycled through biological pathways $[9,28]$.

\section{Effect of Anions and Cations on the Sorption/Desorption of Metal(Loid)s on/from Soil Components}

\section{Sorption of Cations}

In soils, inorganic and organic ligands (L) can affect the interactions between polyvalent cations and soil components. Many factors such as $\mathrm{pH}$, the surface properties of the sorbents, and the nature and charge of Me-L species in solution influence the sorption of metal cations onto soil components and soils $[2,14]$. Metal sorption may be either enhanced or inhibited by the presence of anions through different processes, including site competition, alteration of surface charge of the sorbent, formation of different complexes in solution, and ternary complex formation between the surface of the soil component, the ligand, and the polyvalent cation (Fig. 2). Ternary surface complexes may be classified as type A, in which the metal ion is bonded to both the sorbent and the organic or inorganic ligand, or type $\mathrm{B}$, in which the ligand is bonded to the sorbent between the surface and the metal ion (Fig. 2). The 


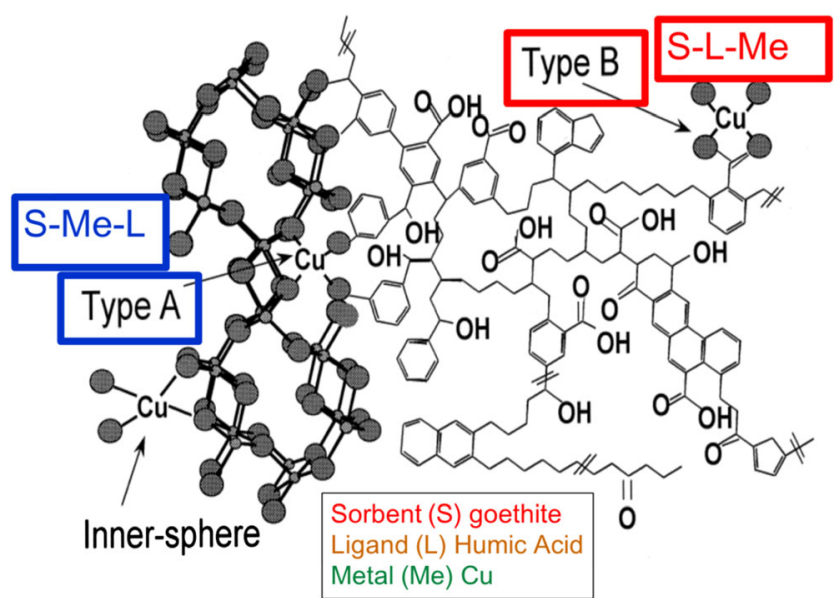

Fig. 2 Illustration of some possible bonding configurations of $\mathrm{Cu}(\mathrm{Me})$ on goethite (S)-humate (L) complexes: inner-sphere complexation of $\mathrm{Cu}$ at goethite sites, and type-A- (S-Me-L) and B-(S-L-Me) ternary complexes (modified from Alcacio et al. [33])

structure of sorbed species determines their stability on the sorbents $[23,24]$.

As reviewed by Violante [6], inorganic (chloride, sulfate, and phosphate) and organic (e.g., oxalate, malonate, malate, tartrate, citrate, fulvate, phthalate) ligands usually inhibit the sorption of metal cations on negatively charged sorbents (phyllosilicates, organic matter, and surfaces of bacteria), by forming stable soluble negatively charged complexes with the cations [34].

Lee et al. $[4,35]$ studied the role of fulvic acid (FA) in modifying the sorption mode of divalent cations $(\mathrm{Ba}, \mathrm{Sr}, \mathrm{Pb}$, $\mathrm{Hg}, \mathrm{Cu}$, and $\mathrm{Zn}$ ) onto the muscovite (001) surface by using in situ resonant anomalous X-ray reflectivity. For less strongly hydrated cations, the presence of FA increased metal sorption in the order $\mathrm{Ba} \approx \mathrm{Sr}<\mathrm{Pb}<\mathrm{Hg}$, in order of increasing cation affinity for FA. Cations with a smaller affinity for FA tend to bind electrostatically on both the surfaces of muscovite and on the negatively charged functional groups of the organic matter, and in soils, they may be easily replaced by background cations as $\mathrm{Ca}$ and $\mathrm{Na}$. Moderately hydrated cations with a greater affinity for organic matter may sorb more strongly on organic matter and are less exchangeable particularly at low $\mathrm{pHs}$, whereas at higher $\mathrm{pH}$ values, these metal-organic complexes are released in solution for electrostatic repulsion between the surfaces of muscovite and the sorbed FA. Finally, the binding of strongly hydrated metals, such as $\mathrm{Cu}$ and $\mathrm{Zn}$, onto the surfaces of muscovite was not altered by FA.

The influence of anions onto the sorption/desorption processes of metal cations on/from variable charge minerals is more complex because organic and inorganic ligands may interact directly with the surfaces of variable charge minerals or metal ions in solution and may thereby alter the sorption/ desorption of metal ions $[2,6]$. In particular, several processes may occur simultaneously: (i) increased retention of metal cations because of the decrease of the positive charge of the mineral when a ligand is sorbed, (ii) increased sorption due to the formation of negatively charged complexes between a metal and a ligand which have a higher affinity for the sorbent, (iii) decreased retention due to the blocking of sorption sites by foreign ligands on the minerals, (iv) decreased retention due to the strong complexation of the metal in solution in non-sorbing forms, which can also lower free metal activity leading to desorption of surface-bound metal, and (v) dissolution of the mineral in the presence of relatively high concentration of chelating organic ligands leading to reduced metal retention [6, 14]. In each of these cases, the influence of a ligand on the sorption of metal cations depends not only on the strengths of the interactions between the metal ion, ligand, and sorbent, but also on their concentrations. Certainly, the initial ligand/metal molar ratio, the nature of the ligand and the metal, and the surface properties of the sorbent seem to be critical in determining whether the sorption of a cation is enhanced or inhibited. Further, because anionic ligands are sorbed more strongly at low $\mathrm{pH}$, whereas metal cations are fixed more easily at high $\mathrm{pH}$, the same ligand may enhance the sorption of a given metal under some conditions but may suppress it under others.

The effect of sulfate and phosphate and low molecular mass organic ligands (LMMOLs) on the sorption of heavy metals has been studied by many authors as reviewed recently by Violante [6]. For instance, phosphates released by Pbearing minerals (e.g., apatite) cause an increase of the $\mathrm{pH}$ up to 6.5-7.5, which induce the complexation and precipitation of heavy metals such as $\mathrm{Cd}, \mathrm{Fe}, \mathrm{Mn}, \mathrm{Ni}, \mathrm{Pb}$, and $\mathrm{Zn}$, as metal phosphates [36, 37]. The enhanced sorption usually observed for some polyvalent cations on metal oxides in the presence of sulfate and phosphate or LMMOLs has been attributed to the increased negative charge brought to the surfaces by these ligands, which promoted electrostatic interactions, or the formation of ternary A- or B-type complexes (Fig. 2), or a mixture of ternary complexes and electrostatics $[38,39]$. Zaman et al. [40] confirmed that the sorption of $\mathrm{Cd}$ on a manganese dioxide was increased by the presence of phosphate. The formation of type-A-ternary complexes was the main mechanism at lower $\mathrm{pH}$, while the formation of typeB-ternary complexes was the predominant mechanism at higher $\mathrm{pH}$ values.

However, a decrease in sorption of some polyvalent cations $(\mathrm{Cd}, \mathrm{Cu})$ in the presence of phosphate has been also observed, probably due to the blocking of surface sites. Using hematite as sorbent, $\mathrm{Li}$ et al. [41] found that phosphate pretreatment suppressed the maximum sorption of $\mathrm{Cd}$ and $\mathrm{Cu}$ because phosphate occupied inner-sphere sorption sites on the surfaces of the sorbents, decreasing inner-sphere sorption sites for metals. Of course, the sorption of phosphate and other ligands with a strong affinity for the surfaces of variable charge minerals (e.g., LMMOLs) also increases the surface negative charges and decreases the electrostatic potential near the solid 
surfaces [42]. However, it is possible that if metal cations are sorbed onto a sorbent mostly forming outer-sphere complexes, their sorption could be increased by the presence of phosphate (and other strongly chelating ligands), whereas, if they form inner-sphere complexes, the presence of anions, which also form strong inner-sphere complexes, suppresses their sorption.

The effect of increasing concentrations of organic ligands on the sorption of metals on soil sorbents has been studied [2, $10,14,43,44]$. By increasing the initial organic ligand/metal molar ratio, the sorption of the metal on a variable charge mineral initially increases and then decreases as compared to its sorption when added alone. At low concentrations, a metal is sorbed, but only occupies a fraction of the surface sites available on a sorbent. If a small amount of a ligand, which binds strongly to both metal and sorbent, is added, more metal will be sorbed, held indirectly to the surface by the ligand. On the other hand, when high concentrations of the ligand are added, the surface sites of the sorbent are saturated by the ligand, reducing metal sorption. Furthermore, a large amount of the metal may be held in solution forming soluble complexes, and hence the sorption is lessened [43].

Liang et al. $[45,46]$ also reported that the presence of arsenate and chromate increased the sorption of $\mathrm{Zn}, \mathrm{Cd}$, and $\mathrm{Cu}$ onto variable charge minerals and soils due to the increase in negative surface charge for the specific adsorption of these anions. However, the heavy metals sorbed through the electrostatic attraction were replaced by neutral salts (e.g., $\mathrm{KNO}_{3}$ ).

In soil environments, many cations are present and compete for the surface sites of the sorbents. Competition in sorption between two or more metal cations is of great importance for understanding their relative affinity for a given sorbent. Competition between two or more cations both in the absence or presence of anions received some attention as reviewed by Violante [6].

Covelo et al. [47] studied the simultaneous sorption and desorption of six heavy metals $(\mathrm{Cd}, \mathrm{Cr}, \mathrm{Cu}, \mathrm{Ni}, \mathrm{Pb}$, and $\mathrm{Zn})$ by kaolinite, vermiculite, mica, Fe- and Mn-oxides, and organic matter. Kaolinite and mica preferentially sorbed $\mathrm{Cr}$, vermiculite $\mathrm{Cu}$, and $\mathrm{Zn}$, while $\mathrm{HA}$ substances and $\mathrm{Fe}$ - and $\mathrm{Mn}$ oxides preferentially fixed $\mathrm{Pb}$ and $\mathrm{Cu}$. More recently, $\mathrm{Zhu}$ et al. [48] studied the competition in sorption among $\mathrm{Pb}, \mathrm{Cr}$, and $\mathrm{Cu}$ added together on ferrihydrite and an organo-mineral complex. When equimolar amounts of each metal were added, the surfaces of ferrihydrite and the organo-mineral complex were covered $>50 \%(53-56 \%)$ by $\mathrm{Pb}, 32-36 \%$ by $\mathrm{Cr}$, and $9-13 \%$ by $\mathrm{Cu}$. However, in the presence of large amounts of $\mathrm{Pb}$ and $\mathrm{Cr}$, some sites were still occupied by $\mathrm{Cu}$ even though $\mathrm{Cu}$ had a much lower affinity than the other two metals for both the sorbents. Evidently, a small proportion of the sites on both sorbents had a high affinity for $\mathrm{Cu}$, particularly on the organo-mineral complex.
$\mathrm{Xu}$ [49] demonstrated that the selectivity sequence of selected heavy metals may change with $\mathrm{pH}$. In fact, this author found that the selectivity sequence of $\mathrm{Pb}, \mathrm{Cu}$, and $\mathrm{Cd}$ sorbed by an Ultisol (as well as by goethite) was $\mathrm{Pb}>\mathrm{Cu}>\mathrm{Cd}$ at $\mathrm{pH}$ 4.2 but it changed to be $\mathrm{Cu}>\mathrm{Pb}>\mathrm{Cd}$ at $\mathrm{pH}$ 5.3. This author also suggested that at low $\mathrm{pH}$, both $\mathrm{Pb}$ and $\mathrm{Cu}$ were sorbed mainly through the formation of surface complexes and consequently $\mathrm{Pb}$ showed a greater capacity to form surface complexes on variable charge surfaces than $\mathrm{Cu}$. At higher $\mathrm{pH}, \mathrm{Cu}$ and $\mathrm{Pb}$ could be sorbed via a hydrolysis mechanism and because the hydrolysis potential of $\mathrm{Cu}$ is greater than that of $\mathrm{Pb}$, more complexes of $\mathrm{Cu}$ with $\mathrm{OH}^{-}$were formed than $\mathrm{Pb}$, which facilitated $\mathrm{Cu}$ sorption versus $\mathrm{Pb}$.

Competition in sorption between two or more metals in the presence of organic or inorganic ligands has received scant attention. Perelomov et al. [44] studied the effect of increasing concentration of $\mathrm{Pb}$ on the sorption of $\mathrm{Cu}$ (initial $\mathrm{Pb} / \mathrm{Cu}$ molar ratio ranging from 0 to 10 ) at $\mathrm{pH} 5.0$ on goethite, in both the absence and presence of oxalate (OX). The OX was added as a mixture with the heavy metals or $1 \mathrm{~h}$ before $\mathrm{Cu}+\mathrm{Pb}$ addition. Lead strongly prevented $\mathrm{Cu}$ sorption, but its inhibition was affected by the initial $\mathrm{Pb} / \mathrm{Cu}$ molar ratio and presence of $\mathrm{OX}$ $(\mathrm{OX} / \mathrm{Cu}+\mathrm{Pb}$ molar ratio of 2$)$. In the absence of $\mathrm{OX}$, the inhibition of $\mathrm{Pb}$ in preventing $\mathrm{Cu}$ sorption increased from 11 to $55 \%$ by increasing $\mathrm{Pb} / \mathrm{Cu}$ molar ratio from 1 to 10 , but the presence of $\mathrm{OX}$ improved $\mathrm{Cu}$ sorption more when added together rather than before the metals.

\section{Sorption of Anions}

The effect of organic and inorganic ligands on the sorption of toxic elements in anionic form (arsenate, arsenite, selenite, chromate, and so on) has received great attention $[2,6,50]$. Indeed, competition between ions is not only competition for the occupancy of sites available onto the surfaces of the sorbents but it also involves a change in charge and then the electric potential of the surface due to sorption of ions and their subsequent penetration of the surface. Competition for surface sites appears evident when the competing anions have a similar affinity for the surface of the sorbent (e.g., arsenate and phosphate), whereas the influence of electric potential is more important when competition occurs between ligands with a great different affinity for the sorbent (e.g., arsenate and sulfate) $[6,51]$.

It has been demonstrated that inorganic and organic anions (e.g., root exudates at the soil/root interface) strongly prevent the sorption of toxic anions (selenite, chromate, arsenate, and arsenite) onto different sorbents [6]. Zhu et al. [52, 53] studied the influence of selected ligands on the sorption of arsenite and arsenate on ferrihydrite and noncrystalline $\mathrm{Al}$ precipitation product. The efficiency of the anions studied in preventing arsenite and arsenate sorption follows this sequence: 
selenate $\approx$ sulfate $<$ oxalate $<$ malate $\approx$ tartrate $<$ citrate $<$ selenite $<<$ phosphate (Table 1 A-B). The efficiency of most of the competing anions in preventing the sorption of the metalloids decreased by increasing the $\mathrm{pH}$. In acidic environments, all the ligands prevented the sorption of arsenite on ferrihydrite more than that of arsenate, but in alkaline systems, arsenite and arsenate seemed to be retained with the same strength. In contrast, on noncrystalline Al oxides, higher sorption of arsenate versus arsenite was always evidenced in a wide range of $\mathrm{pH}$, both in the absence or presence of organic ligands. Caporale et al. [26, 27] evaluated the arsenite and arsenate sorption capacity of a $\mathrm{Al}-\mathrm{Mg}$ and a $\mathrm{Fe}-\mathrm{Mg}$ layered double hydroxide at varying $\mathrm{pH}$ values in the presence of many anions. They also observed that Fe-Mg-LDH sorbent was able to hold a much higher amount of arsenate than arsenite and noted that the sorption of the former was much more $\mathrm{pH}$ dependent than the latter. These authors also found that greater percentages of arsenite than arsenate were replaced by selected ligands according to this sequence: nitrate $<$ nitrite $\approx$ sulfate $<$ tartrate $<$ oxalate $<$ selenite $<<$ phosphate (Table $1 \mathrm{C}$ ).

\section{Coprecipitation Versus Sorption}

In soil environments (e.g., rhizosphere), metal(loid)s are not only sorbed onto the external surfaces of soil components but may be also coprecipitated with $\mathrm{Al}$ and $\mathrm{Fe}$ ions. Some studies were carried out by Violante et al. [54-56] on samples formed by coprecipitating arsenate with aluminum and/or iron. These authors demonstrated that less
Table 1 Sorption $\left(\mathrm{mmol} \mathrm{kg}^{-1}\right)$ of arsenite and arsenate in absence and presence of competing anions (initial anion/arsenite or arsenate molar ratio of 1.0), at $\mathrm{pH} 6.0$ and $20^{\circ} \mathrm{C}$, and efficiency (\%) (i.e., efficiency of the anions in inhibiting arsenite or arsenate sorption on sorbent surfaces) on ferrihydrite (A) [52], noncrystalline $\mathrm{Al}$ oxides (B) [53], and $\mathrm{Mg}$ Fe-LDH (C) [26, 27]

\begin{tabular}{|c|c|c|c|c|}
\hline \multirow[b]{2}{*}{ Anion } & \multicolumn{2}{|l|}{ Arsenite } & \multicolumn{2}{|l|}{ Arsenate } \\
\hline & Sorption (mmol kg ${ }^{-1}$ ) & Efficiency $(\%)$ & Sorption $\left(\mathrm{mmol} \mathrm{kg}^{-1}\right)$ & Efficiency $(\%)$ \\
\hline \multicolumn{5}{|l|}{ Ferrihydrite (A) } \\
\hline As alone & $969.1 \pm 18.4$ & - & 600.0 & - \\
\hline As + sulfate & $954.4 \pm 22.3$ & 1.5 & 600.0 & 0.0 \\
\hline As + selenate & $948.2 \pm 19.0$ & 2.2 & 600.0 & 0.0 \\
\hline As + selenite & $753.1 \pm 16.8$ & 22.3 & $485.2 \pm 12.8$ & 19.1 \\
\hline As + phosphate & $501.0 \pm 14.2$ & 48.3 & $344.8 \pm 8.7$ & 41.1 \\
\hline As + oxalate & $893.4 \pm 25.1$ & 7.8 & $568.2 \pm 13.9$ & 5.3 \\
\hline As + malate & $839.0 \pm 19.7$ & 13.4 & $515.7 \pm 15.8$ & 11.9 \\
\hline As + tartrate & $837.4 \pm 14.8$ & 13.6 & $509.1 \pm 11.5$ & 13.0 \\
\hline As + citrate & $778.4 \pm 17.4$ & 19.7 & Not determined & - \\
\hline \multicolumn{5}{|c|}{ Noncrystalline Al oxides (B) } \\
\hline As alone & $82.8 \pm 2.6$ & - & $249.5 \pm 11.3$ & - \\
\hline As + sulfate & $68.0 \pm 1.8$ & 17.8 & $244.1 \pm 10.0$ & 2.2 \\
\hline As + selenate & $67.2 \pm 2.0$ & 18.8 & $243.9 \pm 12.8$ & 2.2 \\
\hline As + selenite & $57.5 \pm 1.6$ & 30.5 & $172.5 \pm 8.3$ & 30.9 \\
\hline As + phosphate & $16.2 \pm 0.9$ & 80.4 & $147.2 \pm 6.9$ & 41.0 \\
\hline As + oxalate & $50.7 \pm 2.8$ & 38.8 & $211.3 \pm 13.5$ & 15.3 \\
\hline As + tartrate & $46.7 \pm 1.8$ & 43.6 & $197.0 \pm 11.6$ & 21.0 \\
\hline As + malate & $40.7 \pm 2.3$ & 50.8 & $166.2 \pm 5.2$ & 33.4 \\
\hline As + citrate & $38.8 \pm 1.5$ & 53.1 & $170.1 \pm 8.7$ & 31.8 \\
\hline \multicolumn{5}{|l|}{ Mg-Fe-LDH (C) } \\
\hline As alone & 1000.0 & - & 2000.0 & - \\
\hline As + nitrate & Not determined & - & $1984.5 \pm 14.0$ & 0.8 \\
\hline As + sulfate & $936.9 \pm 66.2$ & 6.3 & $1978.4 \pm 21.9$ & 1.1 \\
\hline As + nitrite & Not determined & - & $1965.0 \pm 31.2$ & 1.7 \\
\hline As + selenite & $834.1 \pm 71.8$ & 16.6 & $1724.0 \pm 65.2$ & 13.8 \\
\hline As + phosphate & $763.4 \pm 52.0$ & 23.7 & $1264.1 \pm 68.8$ & 36.8 \\
\hline As + tartrate & Not determined & - & $1844.0 \pm 77.7$ & 7.8 \\
\hline As + oxalate & $932.8 \pm 52.6$ & 6.7 & $1823.9 \pm 52.1$ & 8.8 \\
\hline As + citrate & $779.4 \pm 47.9$ & 22.0 & $1741.9 \pm 72.5$ & 12.9 \\
\hline
\end{tabular}


arsenate was replaced by phosphate from arsenate iron and/or aluminum coprecipitates than from previously formed iron and/or aluminum oxides on which arsenate was sorbed [57]. Low amounts of arsenate coprecipitated with aluminum and/or iron oxides at $\mathrm{pH} 7.0$ were removed by phosphate (5-25\%), attributed to the formation of strong inner-sphere complexes, metal-arsenate precipitates, and partial occlusion of arsenate into the coprecipitates. A comparison of the desorption of arsenate by phosphate from aluminum-arsenate, iron-arsenate, and iron-aluminum-arsenate coprecipitates evidenced that phosphate desorbed more arsenate from aluminum-arsenate, iron-aluminum-arsenate than iron-arsenate coprecipitates (in the order listed), because arsenate forms stronger complexes with $\mathrm{Fe}$ than with $\mathrm{Al}$.

Recently, Sommella et al. [58] investigated the nature and reactivity of $\mathrm{Mg}-\mathrm{Al}-$ arsenate coprecipitated $\mathrm{LDHs}$ formed in solution affected by $\mathrm{pH}$, As content, aging, and temperature. Arsenic coprecipitation, indeed, is one of the major processes controlling As solubility in soils and waters. These authors demonstrated that (i) As(V) retards or inhibits the formation and transformation of LDHs, and (ii) more $\mathrm{As}(\mathrm{V})$ is removed from solution if coprecipitated with $\mathrm{Mg}$ and $\mathrm{Al}$ than by sorption onto well-crystallized LDHs. A schematic representation of the effect of $\mathrm{pH}$, As content, aging, and temperature on the nature of $\mathrm{Mg}-\mathrm{Al}$-arsenate-coprecipitated LDHs was provided by Fig. 3. Therefore, when As is coprecipitated with $\mathrm{Al}$ and $\mathrm{Mg}$, the possible formation of LDHs and/or other nanocomposites can stabilize As in their structures, thus making this toxic element less available.

In contrast to sorption studies, relatively scant information is available on the desorption of metal(loid)s from soil components and soils as affected by ligands as reviewed by Violante et al. [2, 6].

\section{Metal(Loid)s Bioavailability, Chemical Fractionation, and Speciation}

A metal(loid) is bioavailable if it is present as (or can be transformed readily into) the free-ion species, if it can move to plant roots on a time scale that is relevant to plant growth and development, and if, once absorbed by the root, it affects the life cycle of the plant [59]. The use of a single well-defined extraction procedure is one of the most common approaches to assess the phytoavailable fraction of elements in soil. In recent years, single extraction methods have been widely applied to study particular solid phase associations of metal(loid)s in soils [60]. Several extractants are used and can be classified according to the intrinsic mechanism involved in the release of elements from soil, such as: (i) the $\mathrm{CaCl}_{2}$ method [61], (ii) the $\mathrm{NH}_{4} \mathrm{NO}_{3}$ method [62], (iii) the EDTA method [63], (iv) the DTPA method [64], and (v) the Mehlich 3 method [65]. Salt solutions such as $\mathrm{NH}_{4} \mathrm{NO}_{3}$ and $\mathrm{CaCl}_{2}$ can only extract elements from the water-soluble and exchangeable phases, while the DTPA extractant is also able to attack organically bound elements [66]. On the other hand, EDTA is known as the best chelator to assess metal mobilization in soils [67]. The data generated by the abovementioned extractions may have some relevance in the understanding of the physicochemical processes that take place in the soil, since they can provide some empirical information on the mechanisms involved in metal(loid)s binding, transformation, and/or release from soil. However, until now, no extraction procedure proved to be suitable to accurately predict the phytoavailability of metal(loid)s [68]. One of the major challenges in field studies has been how to correlate the results from single extraction assays with metal(loid)s uptake and accumulation by plants.
Fig. 3 Schematic representation of the effect of $\mathrm{pH}$, As content, aging, and temperature on the nature of $\mathrm{Mg}-\mathrm{Al}$-arsenate coprecipitated layered double hydroxides $(L D H s)$ (modified from Sommella et al. [58])

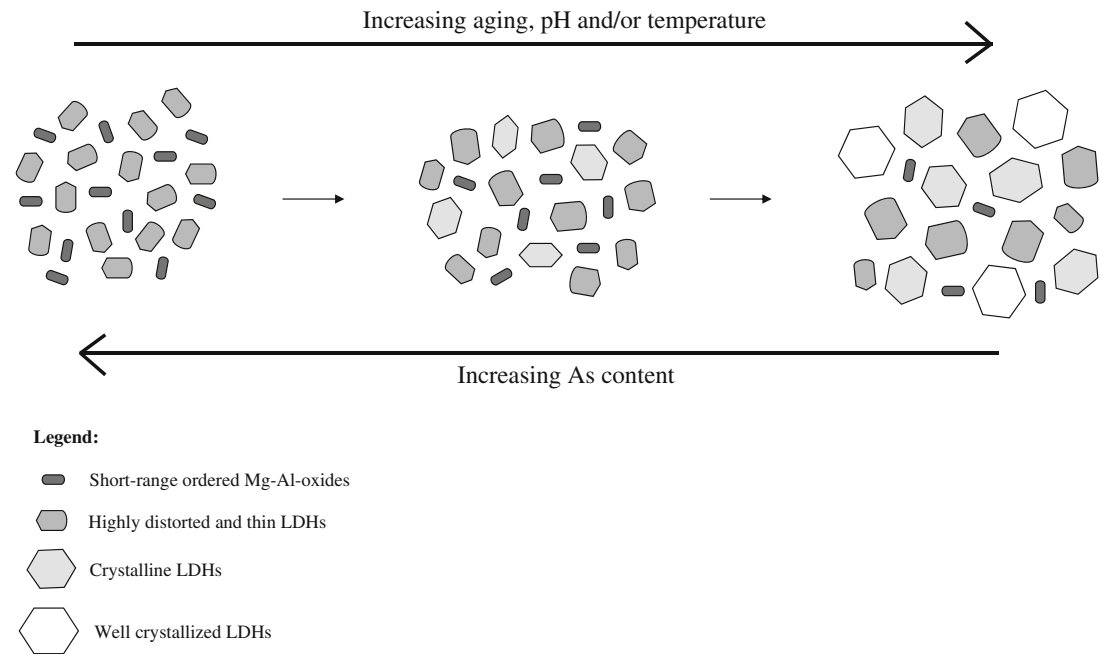


Beside single extraction methodologies, in the last years, many sequential extraction procedures have been developed to identify the main binding sites and phase associations of trace elements in soils [69]. A widely used technique for understanding element distribution in the solid phase (i.e., fractionation) is based on the application of sequential selective chemical extractions [70-72]. These methods are based on the rational use of a series of more or less selective reagents chosen to solubilize successively the different mineralogical fractions which may be responsible for retaining the larger part of the trace elements. They are intended to simulate the various possible natural and anthropogenic modifications of environmental conditions [73].

One of the most widely applied procedures was proposed more than 30 years ago by Tessier et al. [74] (Table 2 A). It partitions elements into five operationally defined geochemical fractions including: (i) exchangeable, (ii) carbonates (acido-soluble), (iii) Fe and Mn oxides (reducible), (iv) organic matter (oxidizable), and (v) residual, to fractionate cadmium, cobalt, copper, iron, lead, manganese, nickel, and zinc in river sediments containing low levels of metal(loid)s. A more sophisticated sequential extraction procedure, which significantly improved the specificity and efficiency of extraction, by a carefully designed combination of various extractants in order to identify the specific species contributing to bioavailability was proposed by Krishnamurti et al. [75] (Table 2 B). Later, Krishnamurti and Naidu [79] modified the sequential extraction scheme developed by Krishnamurti et al. [75], subfractionating the trace element bound to metal-organic complexes as extracted by $0.1 \mathrm{M}$ sodium pyrophosphate [2]. This fraction may contain metal associated with both humic and

Table 2 Sequential extraction procedures described by Tessier et al. (A) [74], Krishnamurti et al. (B) [75], BCR (C) [76, 77], and Wenzel et al. (D) [78]

\begin{tabular}{|c|c|c|c|}
\hline Step & Fraction & Extractant & Operating conditions \\
\hline \multicolumn{4}{|c|}{ Tessier procedure (A) } \\
\hline 1 & Exchangeable & $\mathrm{MgCl}_{2}(1 \mathrm{M}) ; \mathrm{pH} 7.0$ & $1 \mathrm{~h}$ at $25^{\circ} \mathrm{C}$ \\
\hline 2 & Bound to carbonates (acid soluble) & $\mathrm{CH}_{3} \mathrm{COONa}(1 \mathrm{M})$ adjusted to $\mathrm{pH} 5.0$ with $\mathrm{CH}_{3} \mathrm{COOH}$ & $5 \mathrm{~h}$ at $25^{\circ} \mathrm{C}$ \\
\hline 3 & Bound to Fe and Mn oxides (reducible) & $\mathrm{NH}_{2} \mathrm{OH} \cdot \mathrm{HCl}(0.04 \mathrm{M})$ in $25 \% \mathrm{CH}_{3} \mathrm{COOH}$ & $6 \mathrm{~h}$ at $96^{\circ} \mathrm{C}$ \\
\hline 4 & Bound to organic matter (oxidable) & $\begin{array}{l}\mathrm{HNO}_{3} / \mathrm{H}_{2} \mathrm{O}_{2} \text { and then } \mathrm{CH}_{3} \mathrm{COONH}_{4}(3.2 \mathrm{M}) \text { in } \\
20 \% \mathrm{HNO}_{3}\end{array}$ & $5 \mathrm{~h}$ at $85^{\circ} \mathrm{C}$ and then $30 \mathrm{~min}$ at $25^{\circ} \mathrm{C}$ \\
\hline 5 & Residual phases & $\mathrm{HClO}_{4}$ and $\mathrm{HF}$ & Microwave digestion \\
\hline \multicolumn{4}{|c|}{ Krishnamurti procedure (B) } \\
\hline 1 & Exchangeable & $\mathrm{Mg}\left(\mathrm{NO}_{3}\right)_{2}(1 \mathrm{M}) ; \mathrm{pH} 7.0$ & $4 \mathrm{~h}$ at $25^{\circ} \mathrm{C}$ \\
\hline 2 & Carbonate-bound (acid soluble) & $\mathrm{CH}_{3} \mathrm{COONa}(1 \mathrm{M}) ; \mathrm{pH} 5.0$ & $6 \mathrm{~h}$ at $25^{\circ} \mathrm{C}$ \\
\hline 3 & Metal-organic complex-bound & $\mathrm{NaP}_{2} \mathrm{O}_{7} \cdot 10 \mathrm{H}_{2} \mathrm{O}(0.1 \mathrm{M}) ; \mathrm{pH} 10.0$ & $20 \mathrm{~h}$ at $25^{\circ} \mathrm{C}$ \\
\hline 4 & Easily reducible metal oxide-bound & $\mathrm{NH}_{2} \mathrm{OH} \cdot \mathrm{HCl}(0.1 \mathrm{M})$ in $\mathrm{HNO}_{3}(0.01 \mathrm{M})$ & $30 \mathrm{~min}$ at $25^{\circ} \mathrm{C}$ \\
\hline 5 & $\mathrm{H}_{2} \mathrm{O}_{2}$ extractable organic-bound & $30 \% \mathrm{H}_{2} \mathrm{O}_{2}$ and then $\mathrm{Mg}\left(\mathrm{NO}_{3}\right)_{2}$ in $20 \% \mathrm{HNO}_{3}$ & $4 \mathrm{~h}$ at $85^{\circ} \mathrm{C}$ and $30 \mathrm{~min}$ at $25^{\circ} \mathrm{C}$ \\
\hline 6 & Amorphous mineral colloid-bound & $\mathrm{NH}_{4} \mathrm{Ox}(0.2 \mathrm{M}) ; \mathrm{pH} 3.0$ & $4 \mathrm{~h}$ at $25^{\circ} \mathrm{C}$ (dark) \\
\hline 7 & Crystalline Fe oxide-bound & $\mathrm{NH}_{4} \mathrm{Ox}(0.2 \mathrm{M})$ in ascorbic acid $(0.1 \mathrm{M})$ & 30 min at $95^{\circ} \mathrm{C}$ \\
\hline 8 & Residual phases & $\mathrm{HF}$ and $\mathrm{HClO}_{4}$ & Microwave digestion \\
\hline \multicolumn{4}{|c|}{ BCR procedure $(\mathrm{C})$} \\
\hline 1 & Acid soluble & $\mathrm{CH}_{3} \mathrm{COOH}(0.11 \mathrm{M})$ & $16 \mathrm{~h}$ at $25^{\circ} \mathrm{C}$ \\
\hline 2 & Reducible & $\mathrm{NH}_{2} \mathrm{OH} \cdot \mathrm{HCl}(0.1 \mathrm{M}) ; \mathrm{pH} 2.0$ & $16 \mathrm{~h}$ at $25^{\circ} \mathrm{C}$ \\
\hline 3 & Oxidable & $\mathrm{H}_{2} \mathrm{O}_{2}$ and then $\mathrm{CH}_{3} \mathrm{COONH}_{4}(1 \mathrm{M})$ & $1 \mathrm{~h}$ at $85^{\circ} \mathrm{C}$ and then $16 \mathrm{~h}$ at $25^{\circ} \mathrm{C}$ \\
\hline $4^{\mathrm{a}}$ & Residual phases & Aqua regia & Microwave digestion \\
\hline \multicolumn{4}{|c|}{ Wenzel procedure (D) } \\
\hline 1 & Non-specifically sorbed & $\left(\mathrm{NH}_{4}\right)_{2} \mathrm{SO}_{4}(0.05 \mathrm{M})$ & $4 \mathrm{~h}$ at $20^{\circ} \mathrm{C}$ \\
\hline 2 & Specifically sorbed & $\left(\mathrm{NH}_{4}\right) \mathrm{H}_{2} \mathrm{PO}_{4}(0.05 \mathrm{M})$ & $16 \mathrm{~h}$ at $20^{\circ} \mathrm{C}$ \\
\hline 3 & $\begin{array}{l}\text { Sorbed on amorphous and poorly-crystalline } \\
\text { Fe and } \mathrm{Al} \text { (hydr)oxides }\end{array}$ & $\mathrm{NH}_{4}$-Ox buffer $(0.2 \mathrm{M}) ; \mathrm{pH} 3.25$ & $4 \mathrm{~h}$ at $20{ }^{\circ} \mathrm{C}$ (dark) \\
\hline 4 & $\begin{array}{l}\text { Sorbed on well-crystallized Fe and } \mathrm{Al} \\
\text { (hydr)oxides }\end{array}$ & $\begin{array}{l}\mathrm{NH}_{4}-\mathrm{Ox} \text { buffer }(0.2 \mathrm{M}) \text { and ascorbic } \\
\quad \text { acid }(0.1 \mathrm{M}) ; \mathrm{pH} 3.25\end{array}$ & $\begin{array}{l}30 \text { min in a water basin at } \\
96{ }^{\circ} \mathrm{C} \pm 3{ }^{\circ} \mathrm{C} \text { in the light }\end{array}$ \\
\hline 5 & Residual phases & $\mathrm{HNO}_{3}$ and $\mathrm{H}_{2} \mathrm{O}_{2}$ & Microwave digestion \\
\hline
\end{tabular}

${ }^{\text {a }}$ Although not officially a step in the sequential extraction, it is recommended that the residue at the end of Step 3 be digested with aqua regia and the sum of the four fractions be compared with the results of a separate aqua regia digestion of the sample 
fulvic acid fractions of soil organic matter which is bound in metal-organic complexes.

Owing to the need of establishing common schemes in Europe for extractable trace metals in soils and sediments, the EC Standards, Measurement and Testing Programme (formerly BCR, Bureau Community of Reference) has sponsored from 1987 several projects focused on single extraction for soils and sequential extraction for soils and sediments [80]. These projects aimed to adopt common procedures for single extractions and sequential extractions of trace metals from soils and sediments: the result was a three-step procedure using acetic acid (step 1: acid soluble fraction); hydroxylamine (step 2: reducible fraction); and hydrogen peroxide (step 3: oxidable fraction) (Table $2 \mathrm{C}$ ). This scheme was then applied to the certification of a sediment reference material (CRM 601) for validation [76, 77]. Although a large number of different protocols have been reported, the Tessier and BCR schemes remain among the most widely used. A comprehensive review of sequential extraction schemes was provided by Filgueiras et al. [81].

Besides the multi-elements sequential extractions described above, some single-element sequential extractions have been also proposed: for instance, Wenzel et al. [78] developed an innovative and simple five-step protocol for arsenic sequential extraction (Table $2 \mathrm{D}$ ), which by using reagents gradually stronger provides the following five As fractions: (i) non-specifically sorbed, (ii) specifically sorbed, (iii) bound to the amorphous and poorly crystalline $\mathrm{Al}$ and Fe (hydr)oxides, (iv) bound to the well-crystallized Al and Fe (hydr)oxides, and (v) residual phases.

However, these schemes have been widely criticized and the great variety of protocols that have been developed reflects the complexity of the problem: (i) lack of uniformity in the procedures, (ii) lack of selectivity of the reagents used, (iii) lack of quality control, (iv) results highly dependent on the procedure used, and (v) misuse of the results as a means for metal(loid)s speciation. Two additional criticisms of these methods included no accounting for re-sorption/precipitation of metal(loid)s (carry over in the next extraction steps) as well as possible over interpretation of the extraction results. Despite these criticisms, the sequential extraction schemes remain widely used and are considered an essential tool in establishing elemental fractionation in soils and sediments [80].

On the other hand, many scientific studies demonstrated that the bioavailability of the metal(loid)s is closely interlinked with their chemical speciation [82-85]. The speciation is the distribution of elements among their various chemical and physical forms, and possible oxidation states. These include their free ions, complexes, ion pairs, and chelates in solution, and their amorphous and crystalline solid phasesall of which influence the reactivity, mobility, and bioavailability of elements [86]. A large number of analytical techniques have been used in attempting to meet the challenges of assessing metal(loid) speciation [84, 87, 88]. Most of these approaches are only useful to investigate a restricted combination of metal(loid)s and environmental compartments (e.g., soil, water, organisms) [85]. For instance, the analytical methods recently developed for arsenic speciation include various sample pretreatment techniques (e.g., solid phase extraction, liquid-liquid extraction, hydride generation, liquid chromatography, and capillary electrophoresis), which offer effective preconcentration/separation and contribute to enhance the sensitivity and selectivity in arsenic speciation when coupling with a suitable detection mode. Of course, the choice of the pretreatment/extraction technique is crucial to ensure a precise and effective speciation of the element, and to minimize any possible alteration of the original arsenic phases. Highperformance liquid chromatography coupling with inductively coupled plasma mass spectrometry and hydride generation atomic spectrometry are proved to be the most powerful methodologies for arsenic speciation in environmental and biological matrices [84].

The main issues of the metal(loid) analytical methods, such as matrix interference and spatial heterogeneity, can be largely overcome by direct spectroscopic techniques such as those offered by synchrotron X-ray absorption spectroscopy (XAS) and its associated instrumentation (optics, monochromators, detectors, etc.). Direct determination of the chemical forms of trace elements in soil samples, indeed, can be achieved by means of various instrumental techniques [89], notably synchrotron-based X-ray radiation fluorescence (SXRF) [90], particle-induced X-ray emission (PIXE) [91], X-ray absorption near edge structure (XANES) [83, 92], and extended X-ray absorption fine structure (EXAFS) [89] spectroscopy.

The power of synchrotron XAS as a metal(loid) speciation tool arises primarily from its element specificity. X-ray absorption spectroscopy measures quantum (energy) and physical (geometric) states of the element of interest based on the transfer (absorption) of energy from incident X-rays (photons) to core electrons of the element [93]. These measurements provide information about the oxidation state, symmetry, and identity of the coordinating ligand environment, and possibly information about more distant neighboring atoms. In addition, solid phase identification is possible if relevant for the system under study. Limited sample preparation requirements, the concomitant ability to preserve original physical and chemical states, and independence from crystallinity add to the advantages of using XAS in environmental investigations. Interpretations of XAS data are founded on sound physical and statistical models that can be applied to spectra of reference materials and mixed phases, respectively. The application of XANES imaging, a new combinatorial approach of X-ray fluorescence spectrometry and XANES spectroscopy at the micron scale, is one of the latest technological advances 
allowing for lateral resolution of chemical states over wide areas due to vastly improved data processing and detector technology [85].

X-ray absorption spectroscopy has only a few, albeit nontrivial, disadvantages. For example, although it is rarely noted, a long time is often required to perform synchrotron XAS analyses, since most synchrotron radiation facilities have only two to three calls for proposals each year (in many cases, 68 months are necessary to pass between submission of the beamtime proposal and actually conducting the XAS analyses). In addition, a high level of expertise is required to both acquire and analyze XAS data correctly. The greatest challenges in using XAS for the determination of metal(loid) speciation in environmental samples are arguably experimental and include the relatively high detection limits of the technique (even though the detectors are becoming more sensitive and flux at facilities are improving to lower detection limits) $[94,95]$, the potential complexity of chemical speciation in environmental samples, and less frequently, ensuring that sample integrity is maintained during analyses (i.e., preventing X-ray beam damage) [85].

\section{Conclusions}

In soil environments, the mobility and bioavailability of toxic elements are affected by many chemical processes as sorption/ desorption on/from soil components (phyllosilicates, organic matter, variable charge minerals, microorganisms), soil complexation, oxidation-reduction, and precipitation-dissolution reactions.

The $\mathrm{pH}$, the surface properties of the sorbents, the presence of cations and anions, and the formation and nature of Me- $\mathrm{L}$ species in solution affect the interactions between metal(loid)s and soil components. The presence of anions may either enhance or inhibit metal cation sorption, whereas usually inhibits the sorption of toxic elements in anionic form.

Competition between two or more metal(loid)s in the absence or presence of cations or anions is a very important chemical process for understanding the mobility of toxic elements and has been receiving increasing attention in the last years.

Many extraction methods (single extraction and sequential extraction procedures) have been used for assessing metal(loid) phytoavailability. Direct determination of the chemical forms of toxic elements may be achieved by spectroscopic analyses (XAS, XANES, EXAFS), which provide information about oxidation state, symmetry, and identity of the coordinating ligand environment, and possible solid phases. These methods may be widely used in the near future.

Acknowledgments This work was supported by the Italian Research Program of National Interest (PRIN), year 2010-2011 (Grant number 2010JBNL17_005).

\section{Compliance with Ethical Standards}

Conflict of Interest On behalf of all authors, the corresponding author states that there is no conflict of interest.

\section{References}

1. Sparks DL. Environmental soil chemistry. 2nd ed. San Diego: Academic; 2002.

2. Violante A, Pigna M, Cozzolino V, Huang PM. Impact of soil physical, chemical and biological interactions on the transformation of metals and metalloids. In: Huang PM, Li Y, Sumner ME, editors. Handbook of soil sciences. Resource management and environmental impact, Chapter 8. Boca Raton: CRC Press, Taylor and Francis Group; 2012.

3. Borda MJ, Sparks DL. Mobility of trace elements in soil environments. In: Violante A, Huang PM, Gadd GM, editors. Biophysicochemical processes of metals and metalloids in soil environments. Hoboken: Wiley; 2008. p. 97-168.

4. Lee SS, Fenter P, Park C, Sturchio NC, Nagy KL. Hydrated cation speciation at the muscovite (001)-water interface. Langmuir. 2010;26:16647-51.

5. Violante A, Krishnamurti GSR, Huang PM. Impact of organic substances on the formation of metal oxides in soil environments. In: Huang PM, Bollag JM, Senesi N, editors. Interactions between soil particles and microorganism: impact on the terrestrial ecosystem. New York: Wiley; 2002. p. 133-88.

6. Violante A. Elucidating mechanisms of competitive sorption at the mineral/water interface. In: Sparks DL, editor. Adv Agr; 2013. p. 111-76.

7. Sparks DL, Ginder-Vogel M. The role of synchrotron radiation in elucidating the biogeochemistry of metal(loids) and nutrients at critical zone interfaces. In: Huang PM, Li Y, Sumner ME, editors. Handbook of soil sciences. Resource management and environmental impact. Boca Raton: HCRC Press, Taylor and Francis Group; 2012.

8. Sparks DL. Advances in the use of synchrotron radiation to elucidate environmental interfacial reaction processes and mechanisms in the earth' critical zone, Chapter 5. In: Xu J, Sparks DL, editors. Molecular environmental soil science. Dordrecht: Springer; 2013. p. $93-114$.

9. Huang PM, Germida JJ. Chemical and biochemical processes in the rhizosphere: metal pollutants. In: Huang PM, Bollag JM, Senesi N, editors. Interactions between soil particles and microorganisms: impact on the terrestrial ecosystem. New York: Wiley; 2002. p. 381438.

10. Violante A, Krishnamurti GSR, Pigna M. Mobility of trace elements in soil environments. In: Violante A, Huang PM, Gadd GM, editors. Biophysico-chemical processes of metals and metalloids in soil environments. Hoboken: Wiley; 2008. p. 169-213.

11. Chenu C, Stotzky G. Interactions between microorganisms and soil particles: an overview. In: Huang PM, Bollag JM, Senesi N, editors. Interactions between soil particles and microorganism: impact on the terrestrial ecosystem. New York: Wiley; 2002. p. 3-40.

12. Strawn DG, Sparks DL. The use of XAFS to distinguish between inner- and outer-sphere lead adsorption complexes on montmorillonite. J Coll Interface Sci. 1999;216:257-69.

13. Kampf N, Scheinost AC, Schultze DG. Oxide minerals. In: Sumner ME, editor. Handbook of soil science. Boca Raton: CRC Press; 2000. p. F125-68.

14. Violante A, Del Gaudio S, Pigna M, Pucci M, Amalfitano C. Sorption and desorption of arsenate by soil minerals and soils in the presence of nutrients and organics. In: Huang Q, Huang PM, 
Violante A, editors. Soil mineral-microbe-organic interactions. Berlin: Springer; 2008. p. 39-69.

15. Mikutta C, Kretzschmar R. Spectroscopic evidence for ternary complex formation between arsenate and ferric iron complexes of humic substances. Environ Sci Technol. 2011;45:9550-7.

16. Sharma P, Ofner J, Kappler A. Formation of binary and ternary colloids and dissolved complexes of organic matter, Fe and As. Environ Sci Technol. 2010;44:4479-85.

17. Sharma P, Rolle M, Kocar B, Fendorf S, Kappler A. Influence of natural organic matter as transport and retention. Environ Sci Technol. 2011;46:546-53.

18. Mitsunobu S, Harada T, Takahashi Y. Comparison of antimony behaviour with that of arsenic under various soil redox conditions. Environ Sci Technol. 2006;40:7270-6.

19. Dousova B, Buzek F, Herzegova L, Machovic V, Lhotka M. Effect of organic matter on arsenic $(\mathrm{V})$ and antimony $(\mathrm{V})$ adsorption in soils. Eur J Soil Sci. 2015;66:74-82.

20. Peak D, Sparks DL. Mechanisms of selenate adsorption on iron oxides and hydroxides. Environ Sci Technol. 2002;36:1460-6.

21. Lafferty B, Ginder-Vogel M, Sparks DL. Arsenite oxidation by a poorly crystalline manganese oxide. 1 . Stirred-flow experiments. Environ Sci Technol. 2010;44:8460-6.

22. Catalano JG, Park C, Fenter P, Zhang Z. Simultaneous inner- and outer-sphere arsenate sorption on corundum and hematite. Geochim Cosmochim Acta. 2008;72:1986-2004.

23. Ha J, Trainor TP, Farges F, Brown Jr GE. Interaction of aqueous $\mathrm{Zn}$ (II) with hematite nanoparticles and microparticles: part 1. EXAFS study of Zn(II) adsorption and precipitation. Langmuir. 2009;25:5574-85.

24. Ha J, Trainor TP, Farges F, Brown Jr GE. Interaction of Zn(II) with hematite nanoparticles and microparticles: part 2. ATR-FTIR and EXAFS study of the aqueous $\mathrm{Zn}$ (II)/oxalate/hematite ternary system. Langmuir. 2009;25:5586-93.

25. Livi KJT, Senesi GS, Scheinost AC, Sparks DL. Microscopic examination of nanosized mixed Ni-Al hydroxide surface precipitates on pyrophyllite. Environ Sci Technol. 2009;43:1299-304.

26. Caporale AG, Pigna M, Dynes JJ, Cozzolino V, Zhu J, Violante A. Effect of inorganic and organic ligands on the sorption/desorption of arsenate on/from Al-Mg and Fe-Mg layered double hydroxides. J Hazard Mater. 2011;198:291-8.

27. Caporale AG, Pigna M, Azam SMGG, Sommella A, Rao MA, Violante A. Effect of competing ligands on the sorption/ desorption of arsenite on/from $\mathrm{Mg}$-Fe layered double hydroxides (Mg-Fe-LDH). Chem Eng J. 2013;225:704-9.

28. Borch T, Kretzschmar R, Kappler A, Van Cappellen P, GinderVogel M, Voegelin A, et al. Biogeochemical redox processes and their impact on contaminant dynamics. Environ Sci Technol. 2010;44:15-23.

29. Sun X, Doner HE. An investigation of arsenate and arsenite bonding structures on goethite by FTIR. Soil Sci. 1996;161:865-72.

30. Fendorf SE. Surface reactions of chromium in soils and waters. Geoderma. 1995;67:55-71.

31. Jiang W, Cai Q, Xu W, Cai Y, Dionysiou DD, O’Shea KE. Cr(VI) adsorption and reduction by humic acid coated on magnetite. Environ Sci Technol. 2014;48:8078-85.

32. Ma B, Kang M, Zheng Z, Chen F, Xie J, Charlet L, et al. The reductive immobilization of aqueous $\mathrm{Se}(\mathrm{IV})$ by natural pyrrhotite. J Hazard Mater. 2014;276:422-32.

33. Alcacio TE, Hesterberg D, Chou JW, Martin JD, Beauchemin S, Sayers DE. Molecular scale characteristics of $\mathrm{Cu}(\mathrm{II})$ bondingin goethite-humate complexes. Geochim Cosmochim Acta. 2001;65: 1355-66.

34. Abollino O, Giacomino A, Malandrino M, Mentasti E. Interaction of metal ions with montmorillonite and vermiculite. Appl Clay Sci. 2008;38:227-36.
35. Lee SS, Nagy KL, Park C, Fenter P. Heavy metal sorption at the muscovite (001)-fulvic acid interface. Environ Sci Technol. 2011;45:9574-81.

36. Liang Y, Cao X, Zhao L, Arellano E. Biochar- and phosphateinduced immobilization of heavy metals in contaminated soil and water: implication on simultaneous remediation of contaminated soil and groundwater. Environ Sci Pollut Res. 2014;21:4665-74.

37. Oliva J, De Pablo J, Cortina JL, Cama J, Ayora C. Removal of cadmium, copper, nickel, cobalt and mercury from water by ApatiteII $^{\mathrm{TM}}$ : column experiments. J Hazard Mater. 2011;194:31223.

38. Zhang GY, Peak D. Studies of Cd(II)-sulfate interactions at the goethite-water interface by ATR-FTIR spectroscopy. Geochim Cosmochim Acta. 2007;71:2158-69.

39. Swedlund PJ, Webster JG, Miskelly GM. Goethite adsorption of $\mathrm{Cu}(\mathrm{II}), \mathrm{Pb}(\mathrm{II}), \mathrm{Cd}(\mathrm{II})$, and $\mathrm{Zn}(\mathrm{II})$ in the presence of sulfate: properties of the ternary complex. Geochim Cosmochim Acta. 2009;73: 1548-62.

40. Zaman MI, Mustafa S, Khan S, Xing B. Effect of phosphate complexation on $\mathrm{Cd}^{2+}$ sorption by manganese dioxide. J Coll Inter Sci. 2009;330:9-19.

41. Li W, Zhang S, Jiang W, Shan XQ. Effect of phosphate on the adsorption of $\mathrm{Cu}$ and $\mathrm{Cd}$ on natural hematite. Chemosphere. 2006;63:1235-41.

42. Wang K, Xing B. Mutual effects of cadmium and phosphate on their adsorption and desorption by goethite. Environ Pollut. 2004;127:13-20.

43. Angove MJ, Wells JD, Johnson BB. Adsorption of cadmium(II) onto goethite and kaolinite in the presence of benzene carboxylic acids. Colloid Surfaces A Physicochem Eng Aspect. 1999;146: 243-51.

44. Perelomov L, Cozzolino V, Pigna M, Violante A. Adsorption of Cu and $\mathrm{Pb}$ on goethite in the presence of low-molecular mass aliphatic acids. Geomicrob J. 2011;28:582-9.

45. Liang J, Xu RK, Tiwari D, Zhao AZ. Effect of arsenate on adsorption of $\mathrm{Zn}(\mathrm{II})$ by three variable charge soils. Aust J Soil Sci. 2007;45:465-72.

46. Liang J, Xu RK, Jiang X, Wang Y, Zhao AZ, Tan WF. Effect of arsenate on adsorption of Cd(II) by two variable charge soils. Chemosphere. 2007;67:1949-55.

47. Covelo EF, Vega FA, Andrade ML. Competitive sorption and desorption of heavy metals by individual soil components. J Hazard Mater. 2007;140:308-15.

48. Zhu J, Pigna M, Cozzolino V, Caporale AG, Violante A Competitive sorption of copper(II), chromium(III) and lead(II) on ferrihydrite and two organomineral complexes. Geoderma. 2010;159:409-16.

49. Xu R. Interaction between heavy metals and variable charge minerals. In: Xu J, Sparks DL, editors. Molecular environmental soil science, Chapter 8. Dordrecht: Springer; 2013. p. 193-224.

50. Violante A, Caporale AG. Biogeochemical processes at soil-root interface. In: Gianfreda L, editor. Biogeochemical processes in the rhizosphere and their influence on plant nutrition. J Soil Sci Plant Nutr 15. 2015;422-48.

51. Barrow NJ, Cartes P, Mora ML. Modification to the Freundlich equation to describe anion sorption over a large range and to describe competition between pairs of ions. J Soil Sci. 2005;56:601-6.

52. Zhu J, Pigna M, Cozzolino V, Caporale AG, Violante A. Sorption of arsenite and arsenate on ferrihydrite: effect of organic and inorganic ligands. J Hazard Mater. 2011;189:564-71.

53. Zhu J, Pigna M, Cozzolino V, Caporale AG, Violante A. Higher sorption of arsenate versus arsenite on amorphous Al-oxide, effect of ligands. Environ Chem Lett. 2013;11:289-94.

54. Violante A, Ricciardella M, Del Gaudio S, Pigna M. Coprecipitation of arsenate with metal oxides: nature, mineralogy 
and reactivity of aluminum precipitates. Environ Sci Technol. 2006;40:4961-7.

55. Violante A, Pigna M, Del Gaudio S, Ricciardella M, Banerjee D. Coprecipitation of arsenate with metal oxides: nature, mineralogy and reactivity of iron(III) precipitates. Environ Sci Technol. 2007;41:8275-80.

56. Violante A, Cozzolino V, Del Gaudio S, Benerjee D, Pigna M. Coprecipitation of arsenate within metal oxides: 3 nature, mineralogy and reactivity of Iron(III)/Al precipitates. Environ Sci Technol. 2009;43:1515-21.

57. Pigna M, Krishnamurti GSR, Violante A. Kinetics of arsenate sorption-desorption from metal oxides: effect of residence time. Soil Sci Soc Am J. 2006;70:2017-27.

58. Sommella A, Caporale AG, Denecke MA, Mangold S, Pigna M, Santoro A, et al. Nature and reactivity of layered double hydroxides formed by coprecipitating $\mathrm{Mg}, \mathrm{Al}$ and $\mathrm{As}(\mathrm{V})$ : effect of arsenic concentration, pH, and aging. J Hazard Mater. 2015;300:504-12.

59. Sposito G. The chemistry of soils. New York: Oxford University Press; 1989.

60. Pinto E, Almeida AA, Ferreira IMPLVO. Assessment of metal(loid)s phytoavailability in intensive agricultural soils by the application of single extractions to rhizosphere soil. Ecotoxic Environ Safety. 2015;113:418-24.

61. Menzies NW, Donn MJ, Kopittke PM. Evaluation of extractants for estimation of the phytoavailable trace metals in soils. Environ Pollut. 2007;145:121-30.

62. ISO. ISO 19730-2008-soil quality-extraction of trace elements from soil using ammonium nitrate solution. Geneva: International Organization for Standardization; 2008.

63. Rauret G, López-Sánchez JF, Bacon J, Gómez A, Muntau H, Quevauviller $\mathrm{Ph}$. Certification of the contents (mass fractions) of $\mathrm{Cd}, \mathrm{Cr}, \mathrm{Cu}, \mathrm{Ni}, \mathrm{Pb}$ and $\mathrm{Zn}$ in an organic-rich soil following harmonised EDTA and acetic acid extraction procedures, BCR700. Report EUR 19774 EN. Brussels: European Commission; 2001. p. 61.

64. ISO. ISO 14870-2011-soil quality - extraction of trace elements by buffered dtpa solution. Geneva: International Organization for Standardization; 2011. p. 4.

65. Schroder JL, Zhang H, Richards JR, Payton ME. Interlaboratory validation of the Mehlich 3 method as a universal extractant for plant nutrients. J AOAC Int. 2009;92:995-1008.

66. Rao CRM, Sahuquillo A, Lopez-Sanchez JF. A review of the different methods applied in environmental geochemistry for single and sequential extraction of trace elements in soils and related materials. Water Air Soil Pollut. 2008;189:291-333.

67. Xie Z, Wu L, Chen N, Liu C, Zheng Y, Xu S, et al. Phytoextraction of $\mathrm{Pb}$ and $\mathrm{Cu}$ contaminated soil with maize and microencapsulated EDTA. Int J Phytorem. 2012;14:727-40.

68. Fedotov PS, Kördel W, Miró M, Peijnenburg WJGM, Wennrich R, Huang PM. Extraction and fractionation methods for exposure assessment of trace metals, metalloids, and hazardous organic compounds in terrestrial environments. Crit Rev Environ Sci Technol. 2012;42:1117-71.

69. Sutherland RA, Tack FMG, Tolosa CA, Verloo MG. Operationally defined metal fractions in road deposited sediment, Honolulu, Hawaii. J Environ Qual. 2000;29:1431-9.

70. Rauret G. Extraction procedures for the determination of heavy metals in contaminated soil and sediment. Talanta. 1998;46:44955 .

71. Rauret G, Lopez-Sanchez JF, Sahuquillo A, Barahona E, Lachica C, Ure AM, et al. Application of a modified BCR sequential extraction (three-step) procedure for the determination of extractable trace metal contents in a sewage sludge amended soil reference material (CRM 483), complemented by a three-year stability study of acetic acid and EDTA extractable metal content. J Environ Monit. 2000;2:228-33.

72. Cornu S, Clozel BL. Extractions séquentielles et spéciation des éléments trace métalliques dans les sols naturels. Analyse critique. Étude et gestion des sols. 2000;7:179-89.

73. Raksasataya M, Kim ND. Kasetsart University Sci J. 1998;16:44.

74. Tessier A, Campbell PGC, Bissom M. Sequential extraction procedure for the speciation of particulate trace metals. Anal Chem. 1979;51:844-51.

75. Krishnamurti GSR, Huang PM, Van Rees KCJ, Kozak LM, Rostad HPW. Speciation of particulate-bound cadmium of soils and its bioavailability. Analyst. 1995;120:659-65.

76. Quevauviller P, Rauret G, Lopez-Sanchez JF, Rubio R, Ure AM, Muntau H. Certification of trace metal extractable contents in a sediment reference material (CRM 601) following a three-step sequential extraction procedure. Sci Total Environ. 1997;205:223-34.

77. Lopez-Sanchez JF, Sahuquillo A, Fiedler HD, Rubio R, Rauret G, Muntau H, et al. CRM 601-a stable material for its extractable content of heavy metals. Analyst. 1998;123:1675-7.

78. Wenzel WW, Kirchbaumer N, Prohaska T, Stingeder G, Lombi E, Adriano DC. Arsenic fractionation in soils using an improved sequential extraction procedure. Anal Chim Acta. 2001;436:309-23.

79. Krishnamurti GSR, Naidu R. Speciation and phytoavailability of cadmium in selected surface soils of south Australia. Aust J Soil Res. 2000;38:991-1004.

80. Gleyzes C, Tellier S, Astruc M. Fractionation studies of trace elements in contaminated soils and sediments: a review of sequential extraction procedures. Trends Anal Chem. 2002;21:451-67.

81. Filgueiras AV, Lavilla I, Bendicho C. Chemical sequential extraction for metal partitioning in environmental solid samples. J Environ Monit. 2002;4:823-57.

82. Gong ZL, Lu XF, Ma MS, Watt C, Le XC. Arsenic speciation analysis. Talanta. 2002;58:77-96.

83. Vodyanitskii YN. Determination of the oxidation states of metals and metalloids: an analytical review. Eurasian Soil Sci. 2013;46: 1139-49.

84. Chen ML, Ma LY, Chen XW. New procedures for arsenic speciation: a review. Talanta. 2014;125:78-86.

85. Gräfe M, Donner E, Collins RN, Lombi E. Speciation of metal(loid)s in environmental samples by X-ray absorption spectroscopy: a critical review. Anal Chim Acta. 2014;822:1-22.

86. Parker DR, Chaney RL, Norvell WA. Chemical equilibrium models: applications to plant nutrition research. In: Loeppert RH, Schwab AP, Goldberg S, editors. Chemical equilibrium and reaction models. Madison: Soil Sci Soc Am. 1995;163-200.

87. Türker AR. Separation, preconcentration and speciation of metal ions by solid phase extraction. Separ Purif Rev. 2012;41:169-206.

88. Harvanová J, Bloom L. Capillary electrophoresis technique for metal species determination: a review. J Liqu Chromatogr. 2015;38: 371-80.

89. Bacon JR, Davidson CM. Is there a future for sequential chemical extraction? Analyst. 2008;133:25-46.

90. Manceau A, Marcus MA, Tamura N, Proux O, Geoffroy N, Lanson B. Natural speciation of $\mathrm{Zn}$ at a micrometer scale in clayey soil using X-ray fluorescence adsorption and diffraction. Geochim Cosmochim Acta. 2004;68:2467-83.

91. Isaure MP, Laboudigue A, Manceau A, Sarret G, Tiffreau C, Trocellier $\mathrm{P}$, et al. Quantitative $\mathrm{Zn}$ speciation in a contaminated dredge sediment by $\mu$-PIXE, $\mu$-SXRF, EXAFS spectroscopy and principal component analysis. Geochim Cosmochim Acta. 2002;66:1549-67. 
92. Bang JS, Hesterberg D. Dissolution of trace element contaminants from two coastal plain soils as affected by $\mathrm{pH}$. J Environ Qual. 2004;33:891-901.

93. Kelly SD, Hesterberg D, Ravel B. Analysis of soils and minerals using X-ray absorption spectroscopy. In: Ulery AL, Drees LR, editors. Methods of soil analysis. Part 5. Mineralogical methods. Madison: Soil Sci Soc Am. 2008;387-464.

94. Karlsson T, Persson P, Skyllberg U. Extended X-ray absorption fine structure spectroscopy evidence for the complexation of cadmium by reduced sulfur groups in natural organic matter. Environ Sci Technol. 2005;39:3048-55.

95. Kirpichtchikova TA, Manceau A, Spadini L, Panfili F, Marcus MA, Jacquet $T$. Speciation and solubility of heavy metals in contaminated soil using X-ray microfluorescence, EXAFS spectroscopy, chemical extraction, and thermodynamic modelling. Geochim Cosmochim Acta. 2006;70:2163-90. 